depending on the amount of clay-size particles. Both $\mathrm{K}$-feldspars and plagioclase occur in appreciable amounts in all samples. Carbonates or evaporite minerals are totally lacking. There is a large variety of diverse minor accessory minerals, including magnetite, hematite, apatite, zircon, epidote, and several unidentified opaque minerals. Goethite was found particularly enriched in Sample 133-5-1, $142 \mathrm{~cm}$. In the sand fractions, feldspars and quartz grains are very fresh in appearance and poorly rounded.

The results are consistent with the postulate that the variegated beds were deposited on a flood plain. Influxes of clastic continental sediments were derived from a varied crystalline source. The absence of evaporite minerals negated the hypothesis of detrital gypsum suggested by shipboard scientists. Poor sorting excludes the possibility that the sediments represent aeolian loess.

\section{Glass Beads}

Of special interest is the occurrence of glass beads in Sample 13-5-1, $142 \mathrm{~cm}$. They are light yellow to yellowish brown, transparent to translucent, and almost perfect spheres ranging from $60 \mu$ to $200 \mu$. The surface of the balls is rough, thus suggesting shrinkage cracks. From 5 grams of initial sample, 15 individual balls could be isolated. Further analysis is under way to determine if the balls are volcanic, or extraterrestrial.

\section{REFERENCE}

Hardie, L. A. and Eugster, H. P., 1971. The depositional environment of marine evaporites: a case for shallow, clastic accumulation. Sedimentology. 16, 187.

\title{
25.2. MINERALOGICAL COMPOSITION OF THE NILE CONE, MEDITERRANEAN RIDGE, AND STRABO TRENCH SANDSTONES AND CLAYS
}

\author{
W. B. F. Ryan and K. Venkatarathnam, Lamont-Doherty Geological Observatory of Columbia University, \\ Palisades, New York, \\ and \\ F. C. Wezel, Instituto di Geologia dell' Università, Palazzo delle Scienze, 95129 - Catania, Italia
}

\section{INTRODUCTION}

It had been proposed that a former Nile subsea distributary system once extended far seaward of the present day Herodotus Abyssal Plain and that clastics of Nile origin might lie beneath surficial layers of pelagic sediment on the deformed Mediterranean Ridge (Hersey, 1965). To test the validity of this hypothesis, ${ }^{1}$ selected samples of both coarse- and fine-grained sediments from Hole 130 on the ridge and Holes 131, 131A on the Nile Cone were analyzed for a comparative mineralogical study. Detrital layers from four piston cores (Vema 10-53, 10-54, 10-55, and 14-128) on the lower Nile Cone and one core (Vema 10-57) on the Herodotus Abyssal Plain were also investigated so as to be able to establish the mineralogical composition of contemporary sediments of known Nile origin. The northern limit of the suspected Nile sedimentary province was explored by additional sampling of interbedded clastics in cores from the Mediterranean Ridge (Piston Core RC9-178), Strabo Trench (Cores 1 and 2, Hole 129B), and the Hellenic Trough (Piston Core V10-64). The locations of the drill cores and piston cores are listed in

\footnotetext{
${ }^{1}$ Discussed in some detail in Chapter 11.
}

Table 1 and are plotted in the physiographic sketch of Figure 1.

The materials investigated consist of (1) loose sand-siltclay layers inferred to be of probable turbidity current origin, (2) dark gray to black terrigenous muds, (3) carbonate rich pelagic oozes, and (4) consolidated siltstones and sandstones.

\section{PROCEDURES}

\section{Coarse-grained Sediment}

The loosely consolidated sands and silts were initially washed and sieved into several size fractions (i.e., 62,88 , 250 and 500 microns). The heavy minerals were subsequently separated from the light minerals in the $>62 \mu$ fraction by settling in bromoform, specific gravity 2.85 . The heavy minerals were mounted in Hydrax on separate glass slides for petrographic analysis.

Selected pieces of sandstones and siltstones were thin sectioned and examined under the petrographic microscope. Parts of these rock slices were disaggregated in dilute hydrochloric acid to remove the calcareous cement and then separated out and concentrated. The mineralogical data, based on counting more than 300 grains, are reported in Tables 2 and 3. 
TABLE 1

Station Locations

\begin{tabular}{|c|c|c|c|c|}
\hline Station & Latitude $\mathrm{N}$ & Longitude $\mathrm{E}$ & $\begin{array}{l}\text { Water Depth } \\
(\mathrm{m})\end{array}$ & $\begin{array}{c}\text { Physiographic } \\
\text { Province }\end{array}$ \\
\hline V10-53 & $33^{\circ} 11.3^{\prime}$ & $29^{\circ} 06^{\prime}$ & 2897 & $\begin{array}{l}\text { Western Nile } \\
\text { Cone }\end{array}$ \\
\hline V10-54 & $32^{\circ} 48^{\prime}$ & $29^{\circ} 37^{\prime}$ & 2445 & $\begin{array}{l}\text { Western Nile } \\
\text { Cone }\end{array}$ \\
\hline V10-55 & $32^{\circ} 46.3^{\prime}$ & $29^{\circ} 23^{\prime}$ & 2520 & $\begin{array}{l}\text { Western Nile } \\
\text { Cone }\end{array}$ \\
\hline V10-57 & $33^{\circ} 21.3^{\prime}$ & $28^{\circ} 25^{\prime}$ & 3115 & $\begin{array}{l}\text { Herodotus Abys- } \\
\text { sal Plain }\end{array}$ \\
\hline V10-64 & $34^{\circ} 23.3$ & $24^{\circ} 06.2^{\prime}$ & 2133 & Hellenic Trough \\
\hline V14-128 & $32^{\circ} 27^{\prime}$ & $29^{\circ} 45^{\prime}$ & 1931 & $\begin{array}{l}\text { Western Nile } \\
\text { Cone }\end{array}$ \\
\hline RC9-178 & $33^{\circ} 46^{\prime}$ & $27^{\circ} 54^{\prime}$ & 2622 & $\begin{array}{l}\text { Mediterranean } \\
\text { Ridge }\end{array}$ \\
\hline Site 129 & $34^{\circ} 20.96^{\prime}$ & $27^{\circ} 04.92^{\prime}$ & 3042 & Strabo Trench \\
\hline Site 130 & $33^{\circ} 36.31^{\prime}$ & $27^{\circ} 51.99^{\prime}$ & 2979 & $\begin{array}{l}\text { Mediterranean } \\
\text { Ridge }\end{array}$ \\
\hline Site 131 & $33^{\circ} 06.39^{\prime}$ & $28^{\circ} 30.69^{\prime}$ & 3035 & $\begin{array}{l}\text { Western Nile } \\
\text { Cone }\end{array}$ \\
\hline
\end{tabular}

Fine-grained Sediment

The samples of terrigenous mud and pelagic oozes were treated with sodium acetate $(\mathrm{pH} 4.5)$ and then washed with distilled water and dispersed in an ultrasonic bath. Oriented slides of clay components, less than $2 \mu$ in size, were made by pipetting the dispersed slurries onto glass slides and then by air-drying at room temperature. All the clays were glycolated and only some samples from widely separated areas were acid- and heat-treated. The treated as well as untreated clay specimens were analyzed on a Siemen's X-ray diffractometer with a Geiger detector using nickelfiltered copper $K_{a}$ radiation. The clay-mineral groups observed in the present study, namely, kaolinite, chlorite, montmorillonite and illite, were identified by their characteristic basal reflection maxima (or peaks). Small quantities of mixed-layer minerals and gibbsite were also occasionally observed. Material that expanded to $17 \AA$ (001) peak upon glycolation was assigned to the montmorillonite group. The illite group (Grim et al., 1937) was identified by diffraction maxima at 10,5 , and $3.3 \AA$ not affected by glycol treatment. Diffraction maxima at $14 \AA$ (non-expanding) and $4.7 \AA$ were attributed to chlorite, and those at $7 \AA$ and $3.5 \AA$ to kaolinite and chlorite. The resolution of the latter peaks was done by the method described by Biscaye

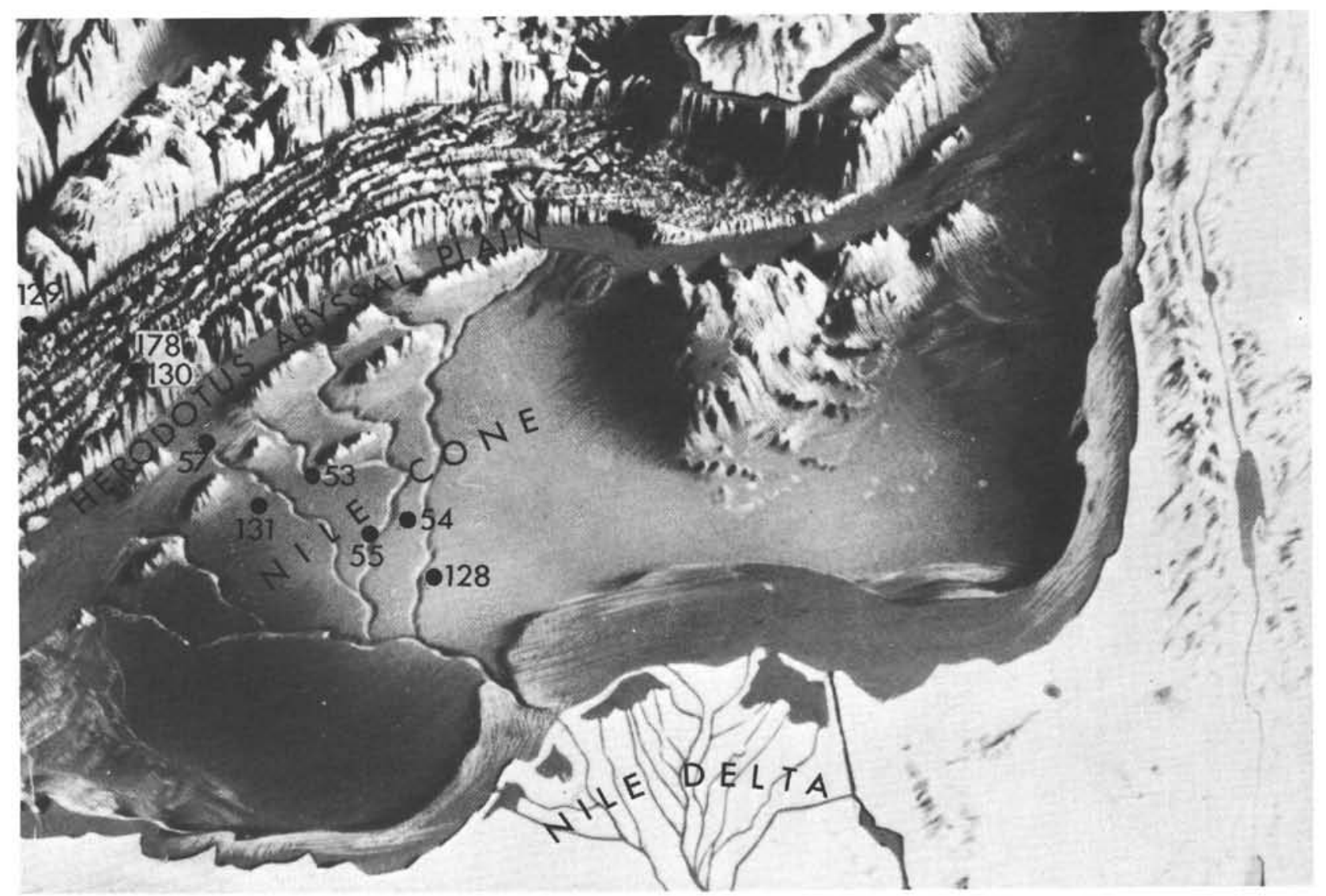

Figure 1. Location of the piston cores and drill holes on the western Nile Cone, Mediterranean Ridge and Strabo Trench. 
TABLE 2

Heavy Mineral Abundances

\begin{tabular}{|c|c|c|c|c|c|c|c|}
\hline Sample & Clinopyroxene & Hornblende & Epidote & Others & Median Size & $\begin{array}{l}\text { Phi Quartile } \\
\text { Deviation }\end{array}$ & General Remarks \\
\hline V10-53 $600 \mathrm{~cm}$ & $31.0 \%$ & $60.0 \%$ & $8.0 \%$ & $1.0 \%$ & & & \\
\hline V10-53 $208 \mathrm{~cm}$ & $35.3 \%$ & $54.7 \%$ & $6.5 \%$ & $3.6 \%$ & & & \\
\hline V10-53 $320 \mathrm{~cm}$ & $39.0 \%$ & $47.0 \%$ & $13.0 \%$ & $1.0 \%$ & & & \\
\hline V10-54 $880 \mathrm{~cm}$ & $7.0 \%$ & $90.0 \%$ & $3.0 \%$ & - & & & \\
\hline V10-55 $285 \mathrm{~cm}$ & $17.2 \%$ & $78.5 \%$ & $3.5 \%$ & $0.9 \%$ & & & \\
\hline V10-57 $520 \mathrm{~cm}$ & $32.9 \%$ & $63.6 \%$ & $3.5 \%$ & - & & & \\
\hline V10-57 $672 \mathrm{~cm}$ & $33.1 \%$ & $55.9 \%$ & $5.5 \%$ & $5.5 \%$ & & & Some olivine present. \\
\hline $130-4-2 \quad 36-38 \mathrm{~cm}$ & $5.0 \%$ & $76.0 \%$ & $19.0 \%$ & - & $2.15 \phi$ & $1.20 \phi$ & Abundant pyrite. \\
\hline $130-4-2 \quad 117-118 \mathrm{~cm}$ & $3.6 \%$ & $73.0 \%$ & $20.0 \%$ & $3.0 \%$ & $1.95 \phi$ & $1.05 \phi$ & $\begin{array}{l}\text { Fine-grained yellowish brown pyrite } \\
\text { opaque, lots of } \mathrm{CaCO}_{3} \text {. }\end{array}$ \\
\hline $130-4-2 \quad 119-120 \mathrm{~cm}$ & $2.0 \%$ & $61.4 \%$ & $30.5 \%$ & $6.0 \%$ & & & \\
\hline 130-7, CC Sandstone & $17.0 \%$ & $67.0 \%$ & $12.0 \%$ & $4.0 \%$ & $3.15 \phi$ & $0.38 \phi$ & $\begin{array}{l}\text { Grain size measurements made after } \\
\text { treatment with } \mathrm{HCl} \text {. }\end{array}$ \\
\hline $131-1-6 \quad 40-41 \mathrm{~cm}$ & $40.0 \%$ & $37.3 \%$ & $11.4 \%$ & $11.4 \%$ & $1.65 \phi$ & $0.32 \phi$ & $\begin{array}{l}\text { Some zircon, garnet, freshly broken } \\
\text { clinopyroxene. }\end{array}$ \\
\hline $131 \mathrm{~A}-1-2 \quad 68-69 \mathrm{~cm}$ & $29.4 \%$ & $57.7 \%$ & $9.4 \%$ & $3.5 \%$ & $2.30 \phi$ & $0.83 \phi$ & $\begin{array}{l}\text { Considerable amounts of zircon, } \\
\text { sphene and clinopyroxene. }\end{array}$ \\
\hline 131A-3, CC Sandstone & $20.0 \%$ & $59.0 \%$ & $15.0 \%$ & $6.0 \%$ & $2.70 \phi$ & $0.30 \phi$ & Includes also zircon. \\
\hline $131 \mathrm{~A}-4-1 \quad 146-147 \mathrm{~cm}$ & $32.0 \%$ & $41.2 \%$ & $16.6 \%$ & $9.0 \%$ & $1.40 \phi$ & $0.90 \phi$ & $\begin{array}{l}\text { Includes zircon, garnet; lots of } \\
\text { freshly broken clinopyroxene. }\end{array}$ \\
\hline
\end{tabular}

TABLE 3

Mineralogy and Texture of the Sandstones

\begin{tabular}{ccccccc}
\hline Sample & Quartz & Feldspar & Calcite & Rock Fragments & Matrix (cement) & General Remarks and Classification \\
\hline $131 \mathrm{~A}-3, \mathrm{CC}$ & $47.0 \%$ & $0.6 \%$ & - & $8.0 \%$ & $44.4 \%$ & $\begin{array}{c}\text { Current bedding laminations present with small mud balls } \\
\text { in an otherwise homogeneous calcite cemented sandstone. } \\
\text { Quartz wacke }\end{array}$ \\
$130-7, \mathrm{CC} 1$ & $42.0 \%$ & $2.0 \%$ & $0.4 \%$ & - & $55.6 \%$ & $\begin{array}{c}\text { Massive texture, no mud balls. } \\
\text { Quartz wacke }\end{array}$ \\
$130-7, \mathrm{CC} 2$ & $41.5 \%$ & $0.4 \%$ & - & $4.4 \%$ & $53.6 \%$ & $\begin{array}{c}\text { Massive texture, one mud ball present. Matrix mainly } \\
\text { calcareous. }\end{array}$ \\
$129 \mathrm{~B}-1, \mathrm{CC}$ & $76.5 \%$ & - & - & $8.5 \%$ & $15.0 \%$ & $\begin{array}{l}\text { Laminations present with very small mud balls cement is } \\
\text { is mainly non-calcareous, probably argillaceous. } \\
\text { Quartz arenite to Quartz wacke }\end{array}$ \\
$129 \mathrm{~B}-2, \mathrm{CC}$ & $12.0 \%$ & $2.0 \%$ & $4.2 \%$ & $20.8 \%$ & $61.0 \%$ & $\begin{array}{l}\text { Non-laminated. Rock fragments include: chert, quartzite, } \\
\text { volcanics, some claystone. Heavy minerals: green horn- } \\
\text { blende and epidote. Cement mostly calcareous. } \\
\text { Lithic sandstone }\end{array}$ \\
V10-64 & $8.5 \%$ & $4.0 \%$ & $5.5 \%$ & $22.0 \%$ & $60.0 \%$ & $\begin{array}{l}\text { Crossbedded and fractured with calcite filled veins. Fine- } \\
\text { grained lithic rock fragments including volcanics (andesite) } \\
\text { and metamorphics. } \\
\text { Lithic sandstone }\end{array}$ \\
\hline
\end{tabular}

(1964), and the mineral identification was verified by acid and heat treatments. The samples with high amounts of chlorite of clay size also have high amounts of this mineral (identified microscopically) in the heavy minerals of silt size.

A semiquantitiative technique (Biscaye, 1965) was used, and the weighted percentages of the different clay minerals were calculated from peak areas. The peaks and the weighting factors used are: $17-\AA$ glycolated peak area for montmorillonite; 4 times the $10 \AA$ (glycolated) for illite; and 2 times the $7 \AA$ peak area (glycolated) for kaolinite and chlorite divided in proportion to the relative areas of their $002(3.58 \AA)$ and $004(3.54 \AA)$ peaks (Biscaye, 1964) respectively. The process of measurement of the peak areas was carried by numerical integration using Simpson's method from digitized tracings of the original diffractograms with a pencil following table-top digitizer. The calculation of the weighted percentages was performed 
from the digitized input data by computer, and is listed in Table 4.

\section{Carbonate Content and Grain Size Analyses}

Additional samples from Holes 130,131 and 131A were analyzed at the Scripps Institution of Oceanography to determine the amount of acid-soluble and insoluble carbon. The procedure is standard for DSDP samples and is discussed by Boyce and Bode (1972). The results are reported in Table 5 in terms of "calcium carbonate" (acid soluble) content and "organic" (acid insoluble) carbon. The grain size distribution was determined by sieving and pipette analysis of another set of samples from the same drill holes. The granulometric data are listed on the core summaries in this volume, in terms of percentages of the sand, silt, and clay fractions (i.e. -1.0 to 4.0 phi=sand; 4.0 to 8.0 phi=silt; finer than $8.0 \mathrm{phi}=$ clay).

\section{HEAVY MINERAL RESULTS}

\section{Nile Cone Sands}

The heavy mineral determinations of sand layers in the piston cores from the western Nile Cone contain a considerable amount of clinopyroxene (augite and diopside) $($ mean $=28.0 \%, \sigma=9 \%)$, green hornblende (mean= $58.5 \%, \sigma=12.3 \%)$ and epidote (mean $=6 \%, \sigma=2.6 \%)$ which are clearly characteristic of detrital materials derived from the Nile distributary system (Shukri, 1950 and 1951; Emelyanov, 1968; Chumakov, 1967). The Site 131 sands recovered from the same region of the Nile Cone (Figure 1) are directly comparable in their clinopyroxene (mean= $30.5 \%, \sigma=5.8 \%$ ) and hornblende (mean $=48.4 \%, \sigma=9.5 \%$ ) contents, and have slightly greater amounts of epidote $($ mean $=13.1 \%, \sigma=2.7 \%)$. The higher epidote content in the Site 131 samples may reflect a slightly different mineral supply in the past since the drill core samples are of an appreciably older Pleistocene age than the surface piston cores. An increase in epidote from 8 per cent $(\sigma=2 \%)$ in youngest Nile River valley deposits $\left(Q_{4}\right.$ formation of

TABLE 4

Clay Mineralogy

\begin{tabular}{|c|c|c|c|c|c|c|c|}
\hline \multirow[b]{2}{*}{$\begin{array}{c}\text { Quantitative Clay } \\
\text { Mineral Measurements }\end{array}$} & \multicolumn{2}{|c|}{$\begin{array}{l}\text { Pelagic } \\
\text { Oozes }\end{array}$} & \multicolumn{5}{|c|}{$\begin{array}{l}\text { Terrigenous } \\
\text { Muds }\end{array}$} \\
\hline & 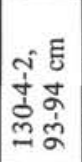 & 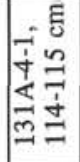 & 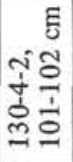 & 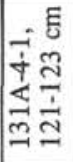 & 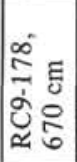 & $\begin{array}{ll}\tilde{n} & E \\
0 & n \\
0 & n \\
> & n\end{array}$ & \begin{tabular}{ll}
$\infty$ & \\
$\sim$ & $E$ \\
\hdashline & $E$ \\
$\dot{1}$ & 0 \\
& 0 \\
$>$ & 0
\end{tabular} \\
\hline $\begin{array}{l}\text { Weighted Peak Area Per- } \\
\text { centage Montmorillonite }\end{array}$ & 38 & 64 & 78 & 85 & 58 & 57 & 52 \\
\hline $\begin{array}{l}\text { Weighted Peak Area Per- } \\
\text { centage Illite }\end{array}$ & 37 & 17 & 6 & 5 & 15 & 14 & 28 \\
\hline $\begin{array}{l}\text { Weighted Peak Area Per- } \\
\text { centage Kaolinite }\end{array}$ & 20 & 15 & 16 & 9 & 26 & 26 & 16 \\
\hline $\begin{array}{l}\text { Weighted Peak Area Per- } \\
\text { centage Chlorite }\end{array}$ & 4 & 2 & 0 & 0 & 0 & 1 & 3 \\
\hline $\begin{array}{l}\text { Ratio Kaolinite/ } \\
\text { Illite }\end{array}$ & 1.11 & 1.69 & 2.60 & 3.29 & 1.73 & 3.64 & 1.62 \\
\hline $\begin{array}{l}\text { Ratio Kaolinite/ } \\
\text { Montmorillonite }\end{array}$ & 0.27 & 0.12 & 0.05 & 0.05 & 0.11 & 0.23 & 0.16 \\
\hline $\begin{array}{l}\mathrm{v} / \mathrm{p} \text { Ratio for } \\
\text { Montmorillonite }\end{array}$ & 0.38 & 0.52 & 0.68 & 0.74 & 0.65 & 0.34 & 0.51 \\
\hline
\end{tabular}

TABLE 5

Carbon and Carbonate Contents

\begin{tabular}{|c|c|c|c|c|}
\hline $\begin{array}{l}\text { Core } \\
\text { Section } \\
\text { Interval }\end{array}$ & $\begin{array}{l}\text { Percentage } \\
\text { of Total } \\
\text { Carbon }\end{array}$ & $\begin{array}{l}\text { Percentage } \\
\text { of Organic } \\
\text { Carbon }\end{array}$ & $\begin{array}{c}\text { Percentage } \\
\text { Calcium } \\
\text { Carbonate }\end{array}$ & Sediment Type \\
\hline \multicolumn{5}{|l|}{ Hole 130} \\
\hline $1-1,112 \mathrm{~cm}$ & 6.1 & 0.7 & 44.8 & Sapropel \\
\hline $1-1,140 \mathrm{~cm}$ & 4.7 & 0.3 & 36.5 & Pelagic \\
\hline $1-1,140 \mathrm{~cm}$ & 9.0 & 0.1 & 73.5 & Pelagic \\
\hline $1-2,80 \mathrm{~cm}$ & 1.2 & 1.0 & 1.9 & Terrigenous \\
\hline $1-2,105 \mathrm{~cm}$ & 9.7 & 3.0 & 55.5 & Sapropel \\
\hline $1-3,30 \mathrm{~cm}$ & 6.3 & 0.2 & 50.3 & Pelagic \\
\hline $1-3,90 \mathrm{~cm}$ & 3.3 & 0.3 & 24.7 & $\begin{array}{l}\text { Drilling mixture } \\
\text { of pelagic and } \\
\text { terrigenous }\end{array}$ \\
\hline $1-4,35 \mathrm{~cm}$ & 1.3 & 1.0 & 2.4 & Terrigenous \\
\hline $1-4,95 \mathrm{~cm}$ & 5.8 & 0.9 & 44.2 & Pelagic \\
\hline $1-4,132 \mathrm{~cm}$ & 8.1 & 0.1 & 66.1 & Pelagic \\
\hline $2-1,105 \mathrm{~cm}$ & 1.5 & 1.2 & 2.7 & Terrigenous \\
\hline $2-2,46 \mathrm{~cm}$ & 4.7 & 0.4 & 36.3 & Pelagic \\
\hline $2-2,79 \mathrm{~cm}$ & 1.0 & 0.5 & 4.2 & Terrigenous \\
\hline $2-3,50 \mathrm{~cm}$ & 1.6 & 0.8 & 6.8 & Terrigenous \\
\hline $2-3,74 \mathrm{~cm}$ & 23.5 & 23.4 & 0.8 & Sapropel \\
\hline $2-3,80 \mathrm{~cm}$ & 7.8 & 0.2 & 63.5 & Pelagic \\
\hline $3-1,120 \mathrm{~cm}$ & 1.2 & 1.1 & 1.4 & Terrigenous \\
\hline $3-1,127 \mathrm{~cm}$ & 7.7 & 0.8 & 57.4 & Pelagic \\
\hline $3-2,80 \mathrm{~cm}$ & 1.8 & 1.2 & 4.7 & Terrigenous \\
\hline $3-2,90 \mathrm{~cm}$ & 9.0 & 0.4 & 71.9 & Pelagic \\
\hline $3-2,104 \mathrm{~cm}$ & 8.7 & 0.6 & 67.3 & Pelagic \\
\hline $4-1,130 \mathrm{~cm}$ & 6.3 & 0.2 & 51.3 & Pelagic \\
\hline $4-2,95 \mathrm{~cm}$ & 7.4 & 0.2 & 60.2 & Pelagic \\
\hline $4-2,105 \mathrm{~cm}$ & 1.4 & 0.9 & 3.8 & Terrigenous \\
\hline $4-2,122 \mathrm{~cm}$ & 8.1 & 0.2 & 66.1 & Pelagic \\
\hline $5-2,90 \mathrm{~cm}$ & 1.4 & 0.9 & 4.3 & Terrigenous \\
\hline $5-3,60 \mathrm{~cm}$ & 1.5 & 0.8 & 6.1 & Terrigenous \\
\hline $6-1,100 \mathrm{~cm}$ & 3.6 & 0.6 & 25.1 & Terrigenous \\
\hline $6-2,95 \mathrm{~cm}$ & 8.3 & 0.2 & 67.5 & Pelagic \\
\hline $6-3,40 \mathrm{~cm}$ & 9.0 & 0.6 & 70.7 & Pelagic \\
\hline $6-4,45 \mathrm{~cm}$ & 9.0 & 0.6 & 70.0 & Pelagic \\
\hline $6-5,30 \mathrm{~cm}$ & 9.4 & 0.5 & 74.0 & Pelagic \\
\hline \multicolumn{5}{|l|}{ Hole 130A } \\
\hline $1-1,94 \mathrm{~cm}$ & 5.8 & 0.1 & 46.8 & Pelagic \\
\hline $1-1,137 \mathrm{~cm}$ & 7.0 & 0.2 & 56.5 & Pelagic \\
\hline \multicolumn{5}{|l|}{ Hole 131} \\
\hline $1-1,71 \mathrm{~cm}$ & 0.3 & 0.1 & 1.6 & Terrigenous \\
\hline $1-2,130 \mathrm{~cm}$ & 0.1 & 0.0 & 0.3 & Terrigenous \\
\hline $1-3,130 \mathrm{~cm}$ & 1.3 & 0.8 & 4.6 & Terrigenous \\
\hline $1-3,50 \mathrm{~cm}$ & 0.2 & 0.1 & 0.9 & Terrigenous \\
\hline $1-4,70 \mathrm{~cm}$ & 0.2 & 0.1 & 1.1 & Terrigenous \\
\hline $1-5,20 \mathrm{~cm}$ & 0.4 & 0.2 & 1.7 & Terrigenous \\
\hline $1-5,35 \mathrm{~cm}$ & 0.2 & 0.1 & 0.5 & Terrigenous \\
\hline
\end{tabular}


TABLE 5 - Continued

\begin{tabular}{|c|c|c|c|c|}
\hline $\begin{array}{l}\text { Core } \\
\text { Section } \\
\text { Interval }\end{array}$ & $\begin{array}{l}\text { Percentage } \\
\text { of Total } \\
\text { Carbon }\end{array}$ & $\begin{array}{c}\text { Percentage } \\
\text { of Organic } \\
\text { Carbon }\end{array}$ & $\begin{array}{l}\text { Percentage } \\
\text { Calcium } \\
\text { Carbonate }\end{array}$ & Sediment Type \\
\hline \multicolumn{5}{|l|}{ Hole 131A } \\
\hline $1-1,110 \mathrm{~cm}$ & 7.4 & 0.2 & 60.0 & Pelagic \\
\hline $1-1,130 \mathrm{~cm}$ & 3.7 & 0.5 & 27.4 & Pelagic \\
\hline $1-2,15 \mathrm{~cm}$ & 7.5 & 0.2 & 60.7 & Pelagic \\
\hline $1-2,90 \mathrm{~cm}$ & 0.9 & 0.6 & 2.7 & Terrigenous \\
\hline $3-1,135 \mathrm{~cm}$ & 1.8 & 1.2 & 5.3 & Terrigenous \\
\hline $4-1,95 \mathrm{~cm}$ & 1.4 & 0.8 & 5.1 & Terrigenous \\
\hline $4-1,112 \mathrm{~cm}$ & 8.7 & 0.1 & 71.5 & Pelagic \\
\hline $4-2,22 \mathrm{~cm}$ & 1.5 & 0.9 & 4.6 & Terrigenous \\
\hline $4-2,136 \mathrm{~cm}$ & 0.5 & 0.3 & 2.0 & Terrigenous \\
\hline $4-3,120 \mathrm{~cm}$ & 0.7 & 0.5 & 2.0 & Terrigenous \\
\hline $5-1,134 \mathrm{~cm}$ & 2.3 & 1.4 & 7.1 & Terrigenous \\
\hline $5-2,2 \mathrm{~cm}$ & 1.8 & 1.2 & 4.5 & Terrigenous \\
\hline
\end{tabular}

Chumakov, 1967$)$ to 14.6 per cent $(\sigma=3.6 \%)$ in older strata of the $Q_{2}$ formation has been established, though its significance has not yet been discussed. In fact, we can see the time relationship best in the individual Hole $131 \mathrm{~A}$ samples with 9.4 per cent epidote at 49 meters below bottom, 15.0 per cent at 140 meters, and 16.6 per cent in Core 4 at 207 meters. Zircon and garnet (mostly almandine) are two other minerals (ultrastable group) present in minor amounts in Site 131 sand layers which are also typically present in fluvial sediments and alluvium of the Nile River valley. They seldom reach more than a couple per cent each in relative abundance. Magnetite and other opaque minerals make up about one-third of the heavy mineral fraction.

\section{Mineralogical Comparison of the Mediterranean Ridge Sands}

The selected samples from Hole 130, on the Mediterranean Ridge some $35 \mathrm{~km}$ seaward of the northern edge of the present day Herodotus Abyssal Plain, are also dominated in the heavy mineral fraction by hornblende, epidote and clinopyroxene, though the relative percentages show some significant differences. For instance, the sand horizons in Core 4 average only around 3.5 per cent clinopyroxene as compared to 28 per cent for the Nile Cone piston cores, but they have relatively high contents of epidote, averaging 23 per cent. As mentioned previously, an increase in epidote has been noted by Chumakov (1967) in older Pleistocene deposits of the Nile Valley. It is also interesting that these same deposits have a clinopyroxene content as low as 5.5 per cent in the $\mathrm{Q}_{2}$ formation and even 1.3 per cent in the still older $\mathrm{Q}_{1}$ formation. Since Core 4 belongs to the Pseudoemiliania lacunosa nannofossil zone of the lower part of the pre-glacial Quaternary, we believe that its mineralogical content, even though not quite the same as that of surface piston cores of the Nile Cone, is still entirely compatible with Nile-derived sediments of equivalent early Quaternary age as established in boreholes of the river valley proper. The decrease in the amount of clinopyroxene could be partly due to the change in grain size. However, we believe that the decrease, as is also true on land in the older Pleistocene deposits (Chumakov, 1962; Butzer and Hansen, 1968), is mainly the result of different inputs by the various tributaries of the Nile River in the early Pleistocene as compared with the subsequent period. Butzer and Hansen (1968) inferred that the Atbara River and, less probably, the Blue Nile, which drain the volcanic rocks of the Ethiopian plateau and thus supply large amounts of clinopyroxene, may have debouched into the Red Sea rather than the Mediterranean prior to Late Pleistocene.

In the light mineral fraction, all the samples are dominated by quartz, generally sub-rounded to rounded and characteristically pitted on its surface (Figure 2). One sample in particular from Core 1 of Hole 131 was comprised of extremely well-rounded grains which indicate the effect of eolian process (Butzer and Hansen, 1968). The frosted texture of the rounded grains, when examined under the scanning electron microscope, is seen to be the result of tiny pits. This pitting may be the result of abrasion by fines in the desert of North Africa as well as chemical etching (i.e., desert dew of Kuenen and Perdok, 1962). The larger indentations, which have a well-defined triangular shape (Figure 3), have been interpreted as percussion marks from high-energy grain impacts in a beach environment (Krinsley and Donahue, 1968).

Potassium feldspars are also present, but form an insignificant part of the bulk sediment composition in this eastern Mediterranean province. The feldspars are mainly plagioclase.

\section{CLAY MINERAL RESULTS}

Only two lithologies were sampled for the less than 2 micron clay mineral analyses. They include the buff-colored calcareous-rich pelagic oozes and the dark gray to black terrigenous clays. The purpose of the investigation was to see whether the mineralogy of the terrigenous clays could be distinguished from the pelagic oozes and if the Mediterranean Ridge clays were of similar composition to clays of known origin in the surface layers of the present Nile Cone. To facilitate the comparisons, the diffractograms of seven samples investigated are shown in Figures 4 and 5.

The terrigenous clays, as typified by Samples 130-4-2, 101-102 cm from the Mediterranean Ridge and 131 A-4-1, $121-123 \mathrm{~cm}$ from the Nile Cone, are strongly dominated by montmorillonite ( 78 and 85 weighted peak area percentage, respectively). This particular montmorillonite (smectite group) is of a generally high "crystallinity" with a v/p ratio of 0.68 and 0.74 . The dark terrigenous clays are also conspicuously low in illite, as seen by the very small $10 \AA$ peak, and have little or no recognizable chlorite in the $3.4 \AA$ range, as shown on the expanded scan on the diffractograms to the right of each trace.

In contrast, the calcareous pelagic oozes at both sites are characterized by considerably greater amounts of both illite and chlorite. In terms of the weighted peak area percentages of the kaolinite, both lithologies would be comparable; however, one can see in Figure 4 that the $3.58 \AA$ peak of the terrigenous clays is invariably higher and better developed than that of the pelagic oozes. This observation probably reflects a greater total abundance of kaolinite in the clays of the Nile River origin (Elgabaly and Khadar, 1962), which however, end up diluted and thus masked by 

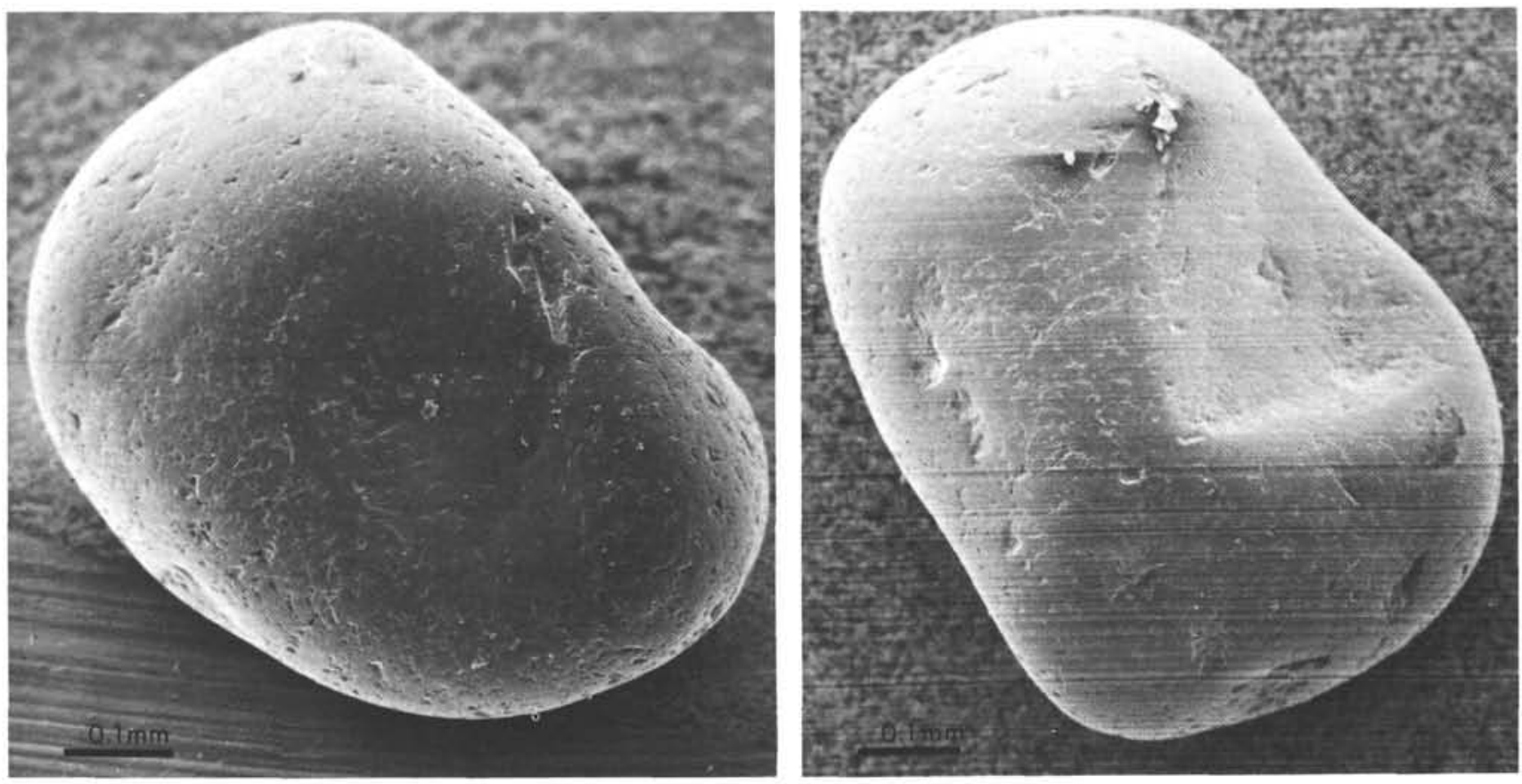

Figure 2. Well-rounded quartz grains from Site 131, Core 1 CC.
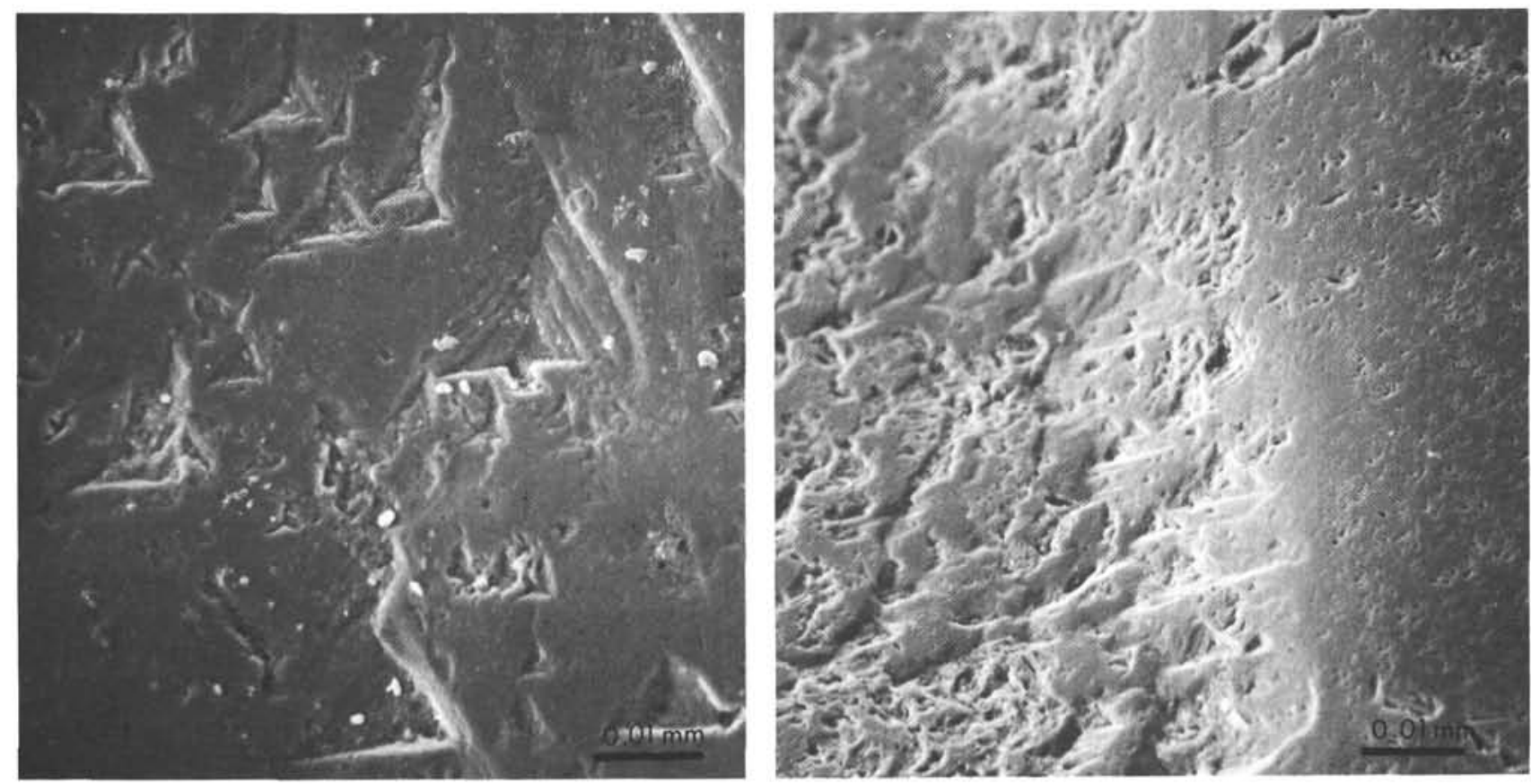

Figure 3. Enlargements of surface textures of the quartz grains illustrated in Figure 2. According to Kuenenand Perdok (1962), the fine-scale pitting seen to the right is believed to be partly formed from solution in desert environments as well as the mechanical action which produces the grain rounding. The large triangular indentations, however, are considered by Krinsley and Donahue (1968) to be diagnostic for littoral or beach environments. Perhaps these sand grains reflect a combination of high energy abrasion processes in coastal dunes on formerly exposed parts of the submarine Nile Delta. 


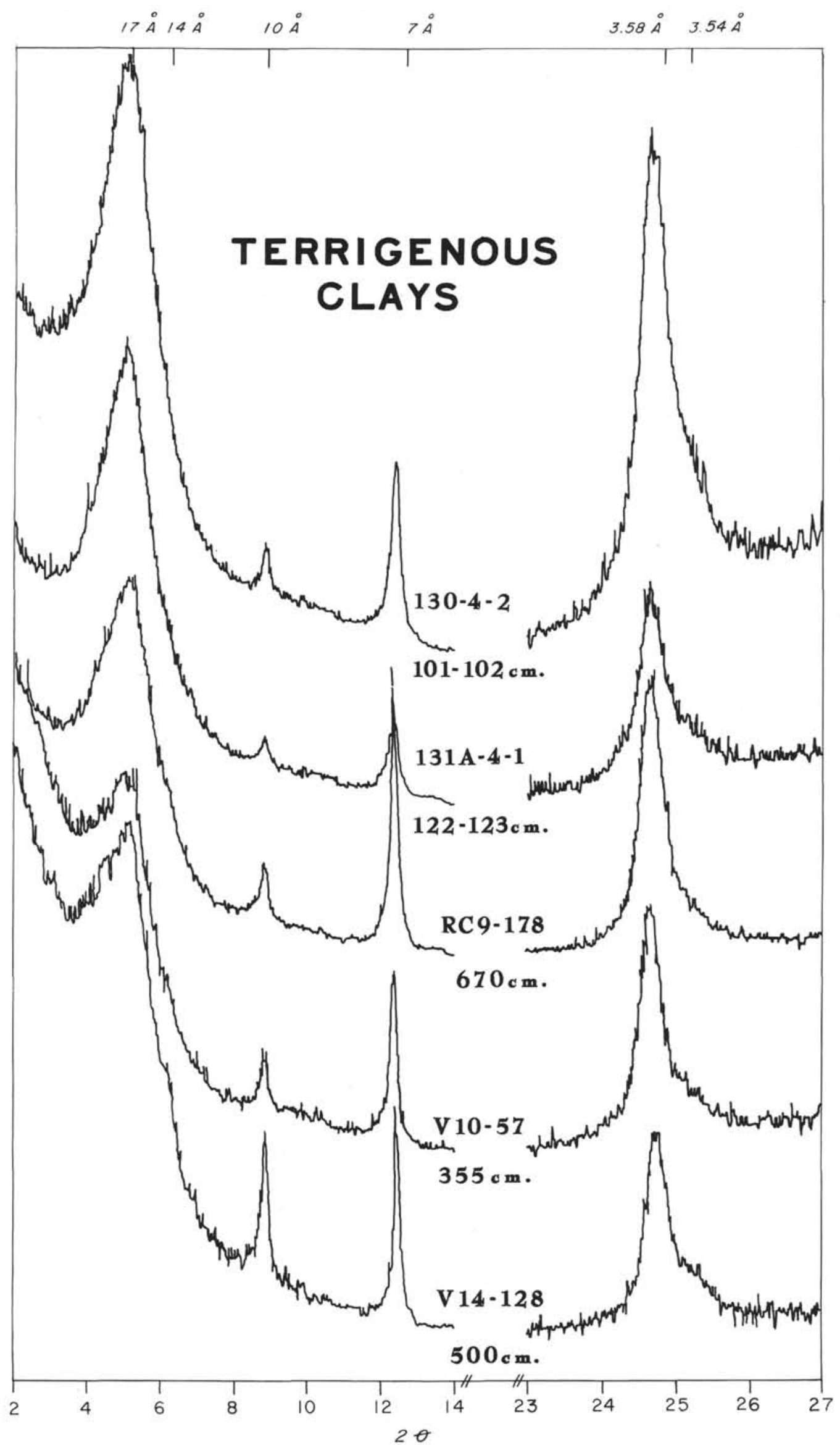

Figure 4. X-ray diffractograms of five samples of terrigenous clay from the Mediterranean Ridge, Nile Cone and Herodotus Abyssal Plain. 
W. B. F. RYAN, K. VENKATARATHNAM, F. C. WEZEL

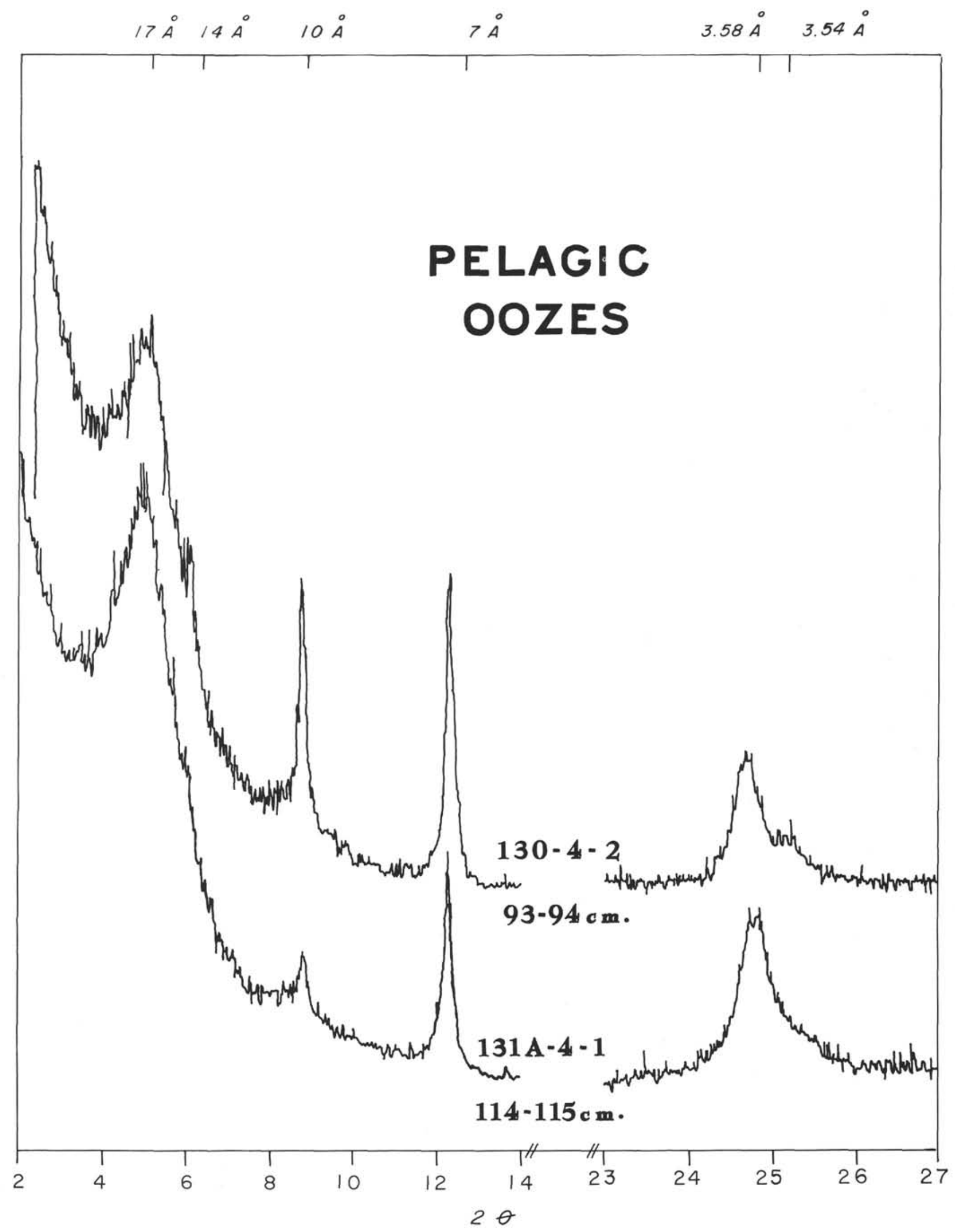

Figure 5. X-ray diffractograms of two samples of pelagic ooze from the Mediterranean Ridge and Nile Cone. 
the vast excess of montmorillonite coming from further up stream.

Not only can the Site 130 terrigenous clay samples from the ridge be compared to the Nile Cone samples at Site 131, but in the same context the RC 9-178 sample also from the ridge is itself identical to the V10-57 sample on the Herodotus Abyssal Plain.

In contrasting the ooze with the clay, however, one does note that the pelagic ooze sample from Site 131 is somewhat affected by the proximity of the terrigenous clay source as revealed by its greater abundance of montmorillonite. The higher content of montmorillonite is repeated in the distribution patterns of the surface sediments of the eastern Mediterranean basins, where uppermost pelagic oozes in piston cores seaward of the Nile Delta characteristically display an appreciable abundance of montmorillonite (Figure 6).

Another criterion to distinguish the terrigenous clay is the ratio of kaolinite/illite (Figure 7). In fact, by this criterion alone it is possible to conclude in terms of fine-grained mineral components that the terrigenous clays found in the Nile Cone, Herodotus Abyssal Plain and subsurface Mediterranean Ridge are all from a common and unique mineral province. From the distribution pattern of both Figures 6 and 7, we can further conclude that these clays are most likely derived from the Nile River. As discussed by Emery and Neev (1960), Emery and George (1963), and Venkatarathnam and Ryan (1971), the dispersal along the coast of Israel and Lebanon of this "Nile Assemblage" simply reflects the strong counterclockwise gyre of the surface water masses of the Levantine basin, and that upon discharge from the delta to the sea the clays are carried for some distance in this water mass.

\section{COMPARISON OF LITHOLOGIES AND TEXTURES}

The terrigenous sediments recovered from the Mediterranean Ridge at Site 130 and from the Nile Cone at Site 131 can also be compared on the basis of their gross lithologies, carbonate content, and sedimentary textures. The cores from both sites are dominated by fine-grained sequences of dark gray to black clays of extremely low carbonate content averaging only 3.3 per cent for some 25 samples investigated (see Table 5). The clays are sometimes accompanied by thin laminae of silt and/or sand at sharp basal contacts of individual bedded sequences and are burrowed, if at all, only at the topmost portion of a bed.

As illustrated in Figure 8, the terrigenous clay layers occur in rhythmic sequences intercalated in a light buffcolored carbonate-rich pelagic foraminifera and nannofossil ooze of Quaternary age. The lower contacts of the ooze layers and the top of a subjacent clay layer are occasionally gradational as a consequence of burrow mottling (Figure 9). The homogeneous nature of most terrigenous clay intervals and their sparseness in marine fauna suggest a relatively rapid emplacement, consistent with the deduced gross rate of accumulation of $55 \mathrm{~cm} / 10^{3} \mathrm{y}$ at Site 130 (see Chapter 11).

Evidence of resedimented materials is apparent with disturbed structures in the sandstones and intraformational breccias in the pelagic oozes (Figure 10). In Core 130-1-1 from the Mediterranean Ridge the illustrated breccia deposit contains plastic fragments of both dark-gray, low-carbonate terrigenous mud and light-buff pelagic ooze in a gray matrix of mixed components. The basal contact of the breccia has been disturbed by the coring process, but still retains its original sharp appearance above subjacent pelagic ooze. In Core 131-1-6 from the western Nile Cone, the resedimentation has involved partly imbricated terrigenous mud pebbles interbedded in a thick layer of graded quartz-rich sand. The mud pebbles are rounded and were probably derived locally from the paleo-surface of the cone or from the walls of submarine channels in the vicinity of the drill site. Similar sedimentary structures have been retrieved from a small distributary channel of the outermost part of the La Jolla fan valley off southern California (Von Rad, 1968). Quite similar mud intraclasts are common in the stable quartzose sandstone beds of the Numidian Flysch (late oligocene to early Miocene) in Tunisia and Sicily (Wezel, 1970).

Mud pebbles of a considerably smaller dimension ("chips" 1 to $2 \mathrm{~mm}$ in diameter) are also found along bedding laminae in graded sand layers of both drill sites. The mud is of a similar lithology to the previously discussed terrigenous clays and is most certainly reworked as is the case of the larger mud balls. In addition, the same fine-grained mud accompanied by calcareous material constitutes the grain matrix of the indurated sandstones.

\section{Texture of the Sandstones}

These sandstones, shown in reverse prints of thin sections in Figure 11, are massive in texture, occasionally with intervals of parallel laminations. It is in the latter intervals that the micro mud balls and chips are most prevalent. The sandstones are dominated by sub-angular to rounded quartz (up to $47 \%$ bulk) and minor amounts of rock fragments of crystalline origin.

X-ray diffraction (see Chapter 24.2) shows that the interstitial cement is low-magnesium calcite, and the tests of foraminifera are often partially or completely filled with sparry calcite. However, the amount of calcite as a detrital component is extremely low. As indicated in Table 3, the sandstones of Sites 130 and 131 are classified as stable quartz sandstones with matrix (composition near $\mathrm{Q}_{85-90}$ $\mathrm{F}_{1} \mathrm{~L}_{14-9}$ ).

Quartz-rich sandstone was also found in Hole 129B (Sample $1 \mathrm{CC}$ ) in the Strabo Trench at the northern boundary of the Mediterranean Ridge. This sandstone was recovered floating in loose sand of similar mineralogy accompanied by foraminiferal tests indicative of a Quaternary age. Although the 129B-1 CC sandstone illustrated in Figure 12 also contains concentrations of mud along laminae, the total interstitial matrix (upper visual limit $\approx 20$ microns) is considerably lower $(15 \%)$ than the Nile Cone sandstones (44\%) and is mainly noncalcareous. Nevertheless, there is enough overall similarity in the bulk composition and texture to suggest that the Site 129, 130, and 131 sandstones shared a similar quartz source, which we deduce to be from the south off Africa rather than from the orogenic metamorphic terrains of southern Turkey or Greece. 


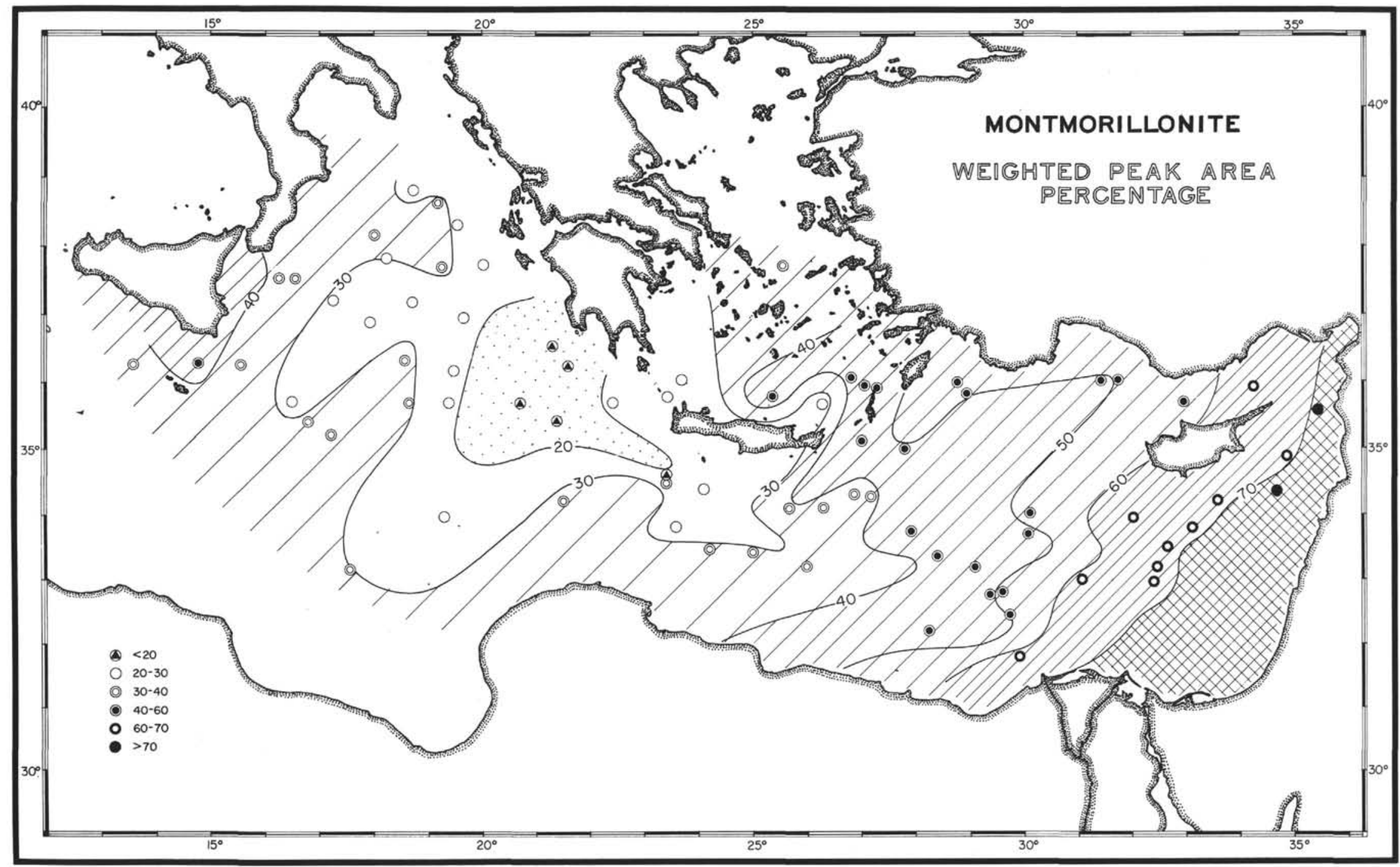




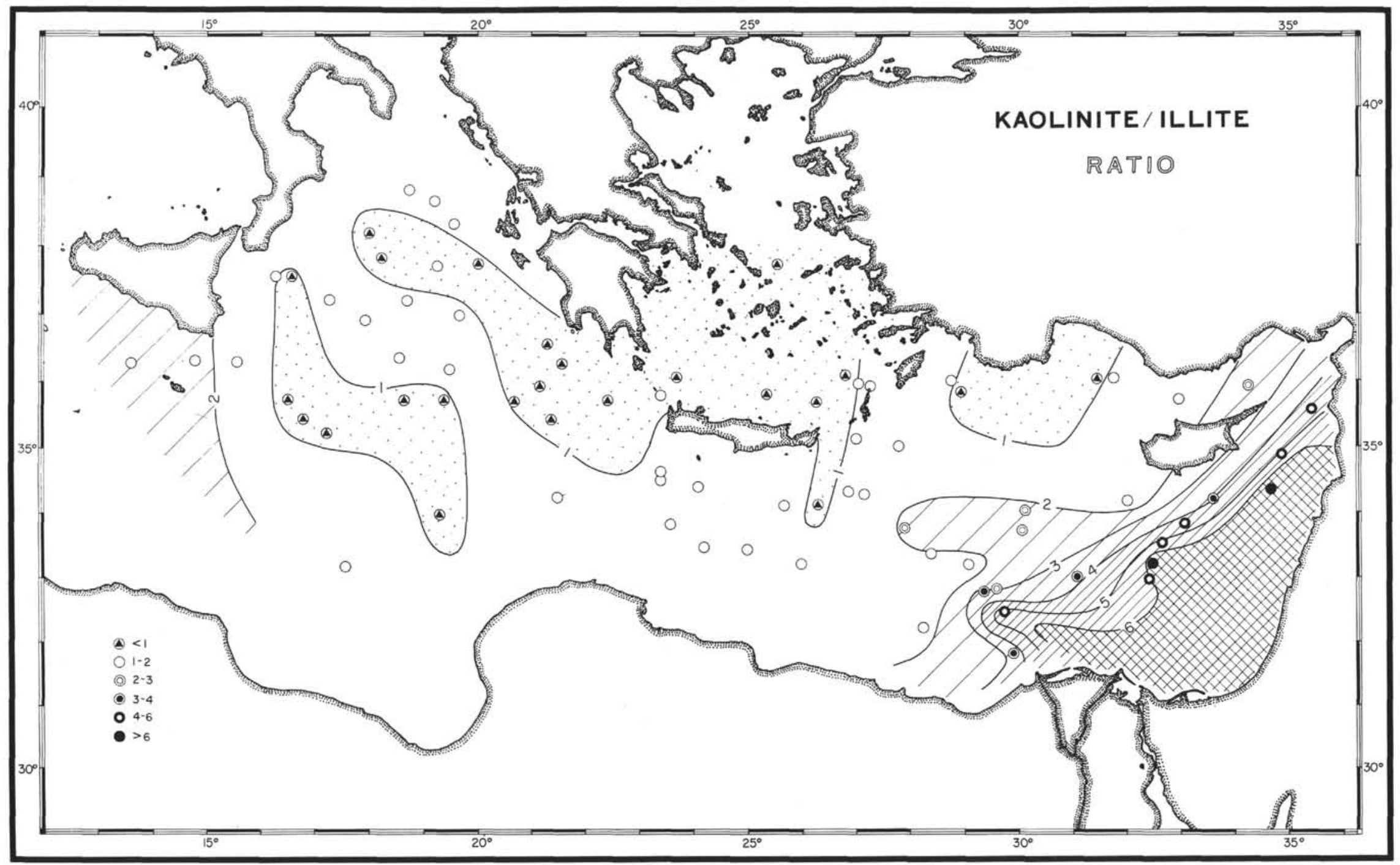

Figure 7. Kaolinite/illite ratio in surface samples of pelagic sedimentation. The distribution of high values along the coast of Israel and Lebanon reflects dispersal of kaolinite-rich Nile sediments into the surface water mass and subsequent transport in the established counterclockwise circulation gyre. 


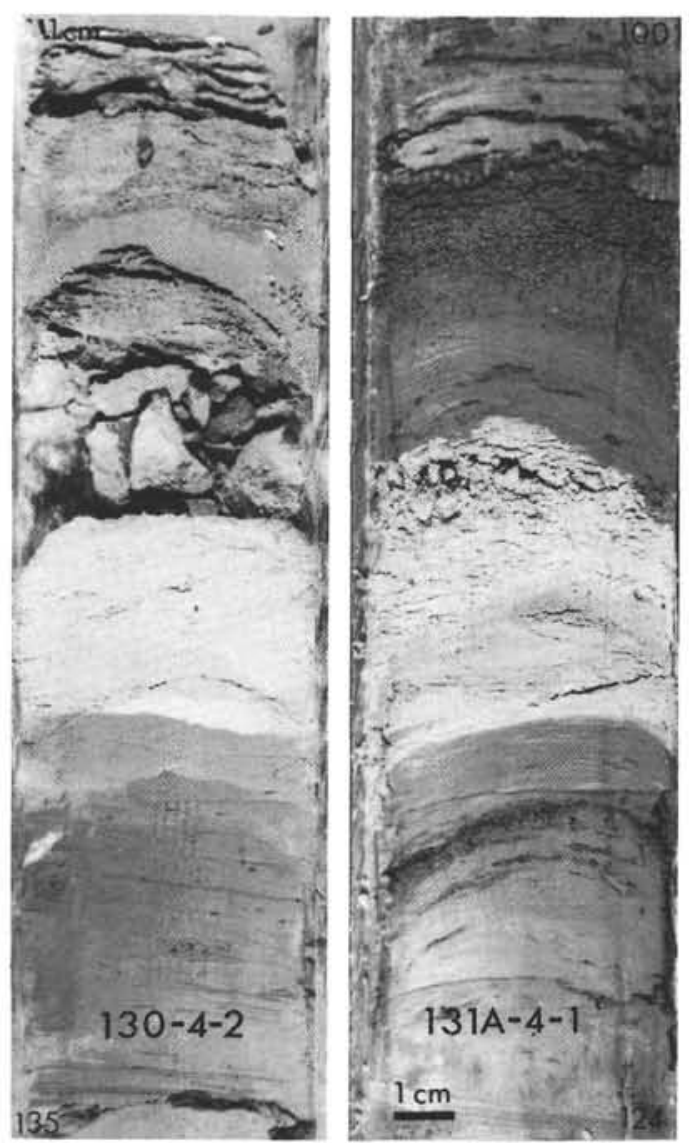

Figure 8. Examples of interbedded buff-colored pelagic oozes (light) in gray to black terrigenous clay with occasional beds of sand and silt. Hole 130 is on the Mediterranean Ridge and $131 \mathrm{~A}$ on the Western Nile Cone.

For comparison to other sedimentary units of established North African origin we offer as an example the Upper Oligocene-Lower Miocene Numidian Flysch of Sicily. In Table 6 we have listed several properties of the sand (coarse clastic) facies from the Nile Cone drill sites and piston cores and sandstone outcrops of Sicily interpreted by Wezel (1970) to represent former continental margin sedimentation. Additional comparisons of the fine-grained facies are offered in Table 7.

\section{Indications of a Northern Provenance}

There is, nevertheless, documentation in samples of sandstone from Hole 129B (2 CC and 3 CC) in the Strabo Trench of a metamorphic and volcanic provenance not in itself attributable to North Africa. This rock, illustrated in Figure 13, contains only 12 per cent quartz (about one-third of the quartz is a polycrystalline-recrystallized and stretched metamorphic type with strong undulatory extinction) and is dominated by lithic rock fragments including andesitic volcanics, metamorphic fragments, chert, mudstone, and broken tests of calcareous foraminifera. Classified as a lithic sandstone $\left(\mathrm{Q}_{34.3} \mathrm{~F}_{5.6} \mathrm{~L}_{60.0}\right)$, the 2 CC sample more directly compares with the Hellenic Trench sand layers of Sites 127 and 128 than with the Nile-derived quartz wackes (Table 8). The age of the
129B-2 CC lithic sandstone is not known. It is difficult to imagine how current bedded clastics of this grain size could get to the Strabo Trench from the north, east or west across the present topographic barrier of the Strabo and Anaximander Mountains. A possible clue is offered from fragments of finer-grained lithic sandstones $\left(Q_{24.6} F_{11.6}\right.$ $\mathrm{L}_{63.8}$ ) similar mineralogic composition in piston core V10-64 within the Hellenic Trough directly south of Crete. This second sample, also illustrated in Figure 13, was embedded in an interformational breccia with other indurated fossiliferous sediments of Middle Miocene (Langhian) age. The V10-64 sandstones are cross-bedded and heavily fractured. Veins are filled with a sparry calcite cement. If the lithic sandstones themselves date from this older period, they perhaps then had a northern source from the formerly orogenically active internal zone of the southern Hellenides and Taurids (Brunn, 1960; Aubouin, 1965). Their distribution seaward of bathymetric depressions and barriers suggests a younger or synchronous tectonism for the Strabo-Anaximander mountains complex, leading to a development of the present day island arc structure along the northern border of the eastern Mediterranean basins (Woodside and Bowin, 1970; Smith, 1971).
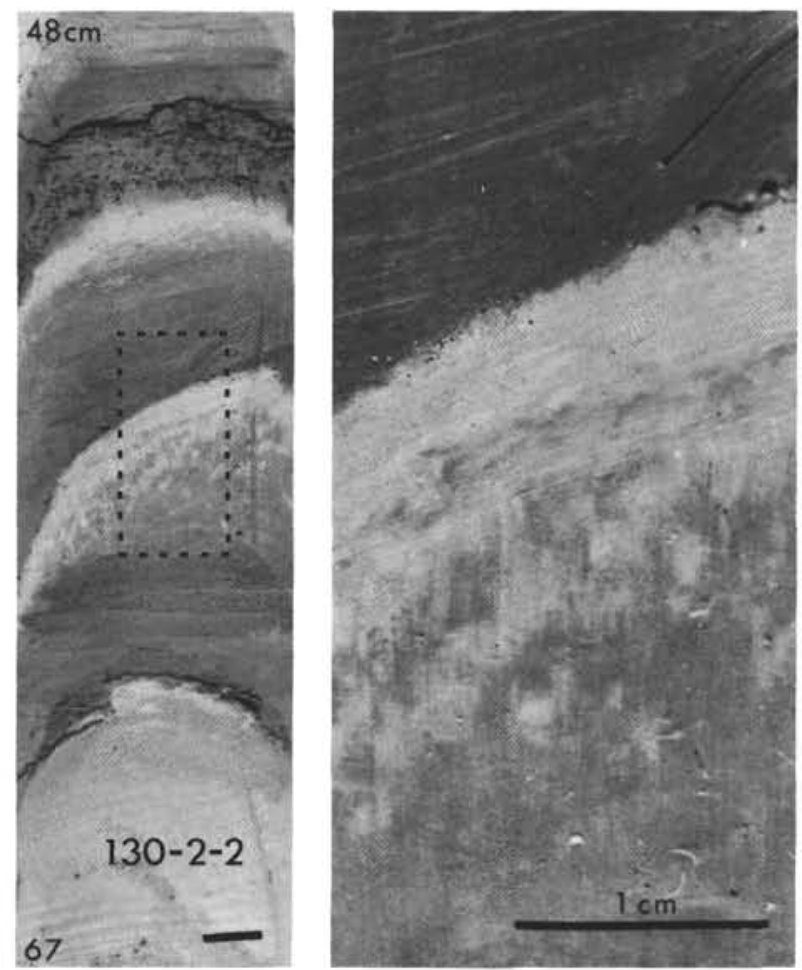

Figure 9. Example of burrow mottling in the lightcolored pelagic oozes. The enlargement shows that the burrowing takes place while the light ooze is being deposited and involves both an upward mixing of terrigenous clay into the ooze as well as a downward mixing of the ooze exclusively into the subjacent clay. This deposit then becomes rapidly blanketed by another terrigenous clay interval. Note the presence of silt and sand in the basal portion of some of the dark terrigenous layers. 

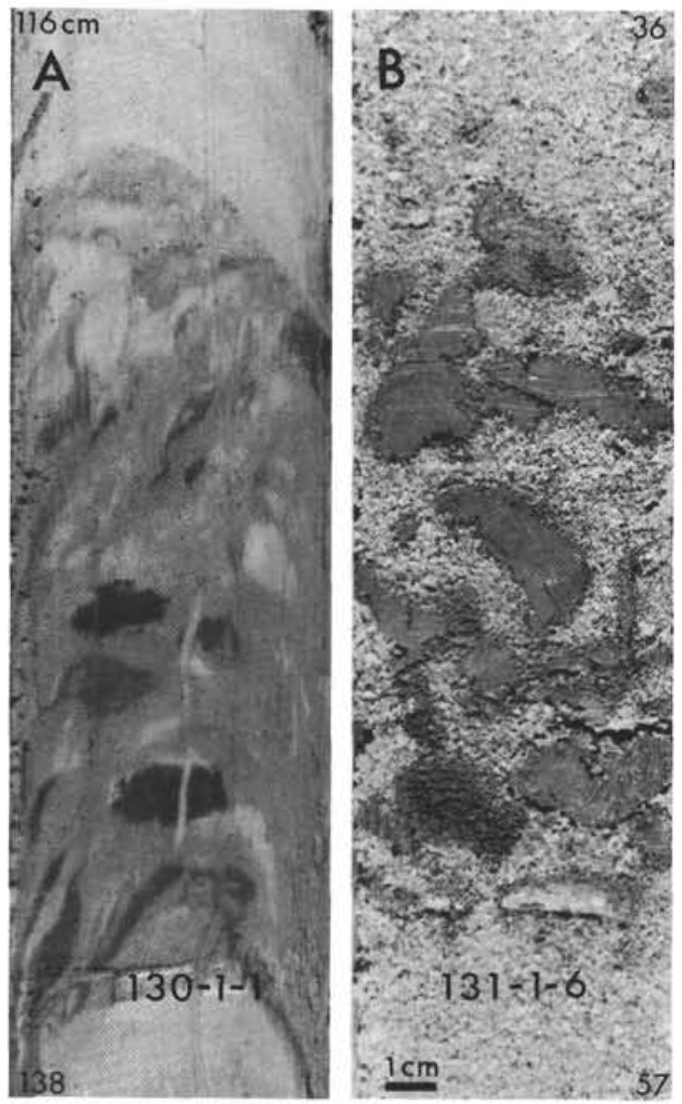

Figure 10. Example of redeposited sediment incorporated within (A) interformational breccias of mixed terrigenous mud-pelagic oozes on the Mediterranean Ridge (130) and (B) mud intraclasts in grainflow deposits on the Nile Cone (131). A burrow track (left center) through several of the lumps of ooze and mud demonstrates that this sedimentary structure was not created during the drilling and coring process.

\section{CONCLUSIONS}

The mineralogic investigations of the Nile Cone, Herodotus Abyssal Plain, and subsurface Mediterranean Ridge detrital sands and terrigenous clays indicate a common sedimentary provenance. From a comparison with present day patterns of sediment transport and dispersal, it is possible to conclude that the input of this sediment into the sea was by way of the Nile Delta. The lack of sands and low-carbonate terrigenous clays in present day surface samples from the Mediterranean Ridge indicates that both the fine- and coarse-grained sediment fraction is transported to the abyssal plain predominantly by gravity-propelled bottom flows (i.e., turbidity current and grainflow mechanisms). The discovery of great thicknesses of terrigenous sediment in the subsurface of the Mediterranean Ridge supports the hypothesis put forward by Hersey (1965) that the ridge is an uplifted and deformed wedge of former basinal sediments of predominant Nile origin. The findings of andesitic and metamorphic rock fragments in lithic graywacke sandstones from the Strabo Trench and Hellenic
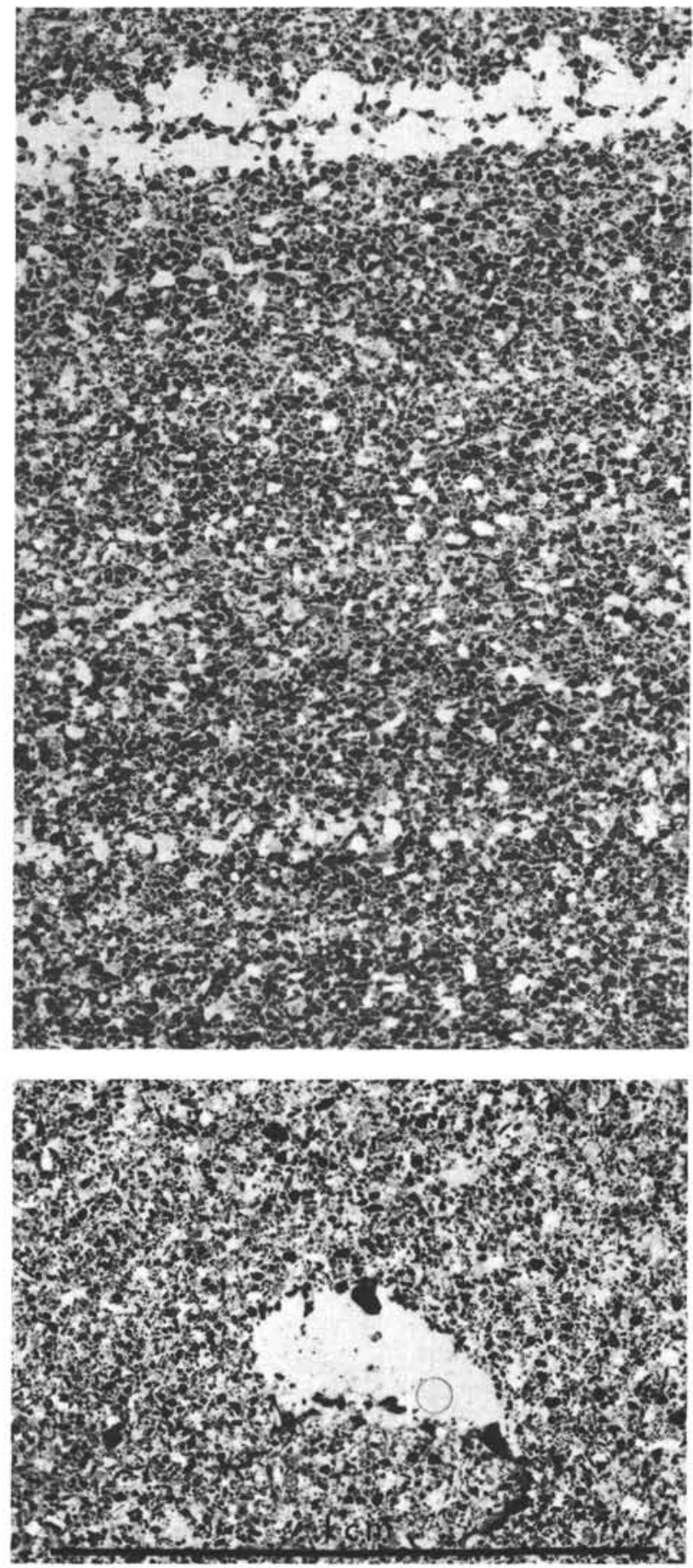

Figure 11. Reversal (negative) prints of thin sections of stable quartz sandstones with matrix from the Nile Cone $(131 \mathrm{~A}, 3 \mathrm{CC}$, top) and Mediterranean Ridge (130, 7 CC, bottom). Note the presence of small mud balls (pebbles) (light) imbricated along bedding laminae, and the occurrence of individual grains of quartz (generally dark) embedded in some of the mud fragments. Fine-grained clay matrix makes up some 55 per cent of the lower slide.

Trough indicates yet another distinct sedimentary provenance, probably associated with an island arc-trench complex (Mitchell and Reading, 1969; Wezel and Ryan, 1971). 


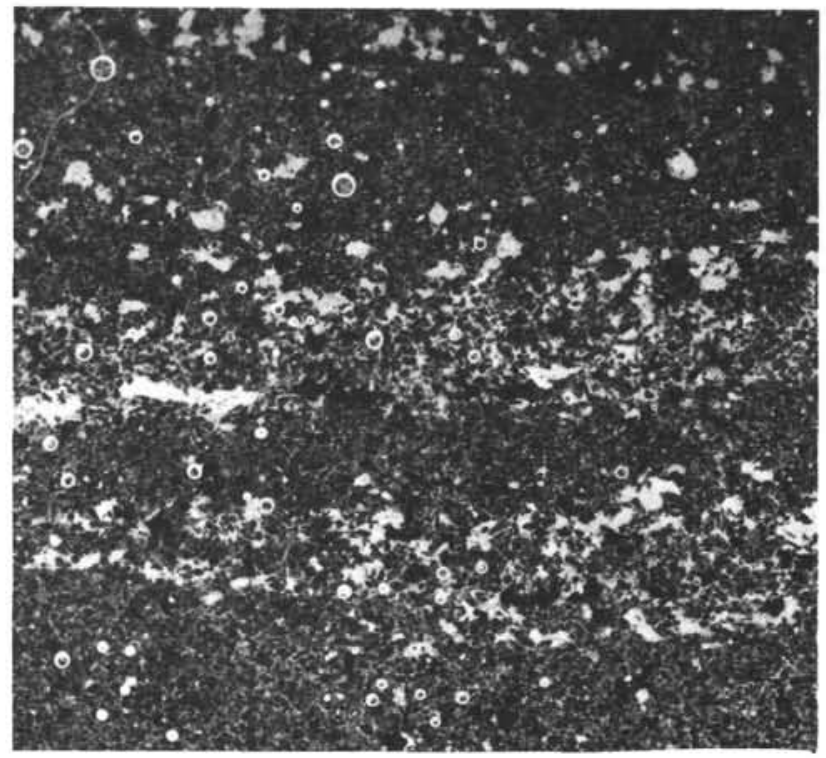

Figure 12. Reversal print of a slightly finer-grained sandstone (Sample 129B, 1 CC) from the Strabo Trench. Although this quartz arenite contains considerably less interstitial matrix, it still has the characteristic micro mud balls along bedding surfaces.

TABLE 6

Comparison of Nile Cone Sands and the North African Numidian Flysch (Facies 1) of Sicily

\begin{tabular}{|c|c|c|}
\hline & $\begin{array}{l}\text { Nile Cone Sands } \\
\text { Site } 131\end{array}$ & $\begin{array}{l}\text { Numidian Flysch of } \\
\text { Sicily-Sandstones } \\
\text { (Wezel, 1970) Facies } 1\end{array}$ \\
\hline $\begin{array}{l}\text { Bed } \\
\text { Thickness }\end{array}$ & Up to $2.9 \mathrm{~m}$ & $\mathrm{Up}$ to $10 \mathrm{~m}$ \\
\hline $\begin{array}{l}\text { Internal } \\
\text { Structure }\end{array}$ & $\begin{array}{l}\text { Massive, homogeneous } \\
\text { beds ungraded }\end{array}$ & $\begin{array}{l}\text { Massive, absent to } \\
\text { poor grading, some- } \\
\text { times repetitive }\end{array}$ \\
\hline $\begin{array}{l}\text { Sands } \\
\text { Base and Top }\end{array}$ & Sharp & Sharp \\
\hline $\begin{array}{l}\text { Mud Pebbles } \\
\text { Within Sand- } \\
\text { stones } \\
\text { (intraclasts) }\end{array}$ & Up to $6 \mathrm{~cm}$ & $\begin{array}{l}\text { Up to } 40 \mathrm{~cm} \\
\text { Common character }\end{array}$ \\
\hline Composition & $\mathrm{Q}_{85-90} \mathrm{~F}_{1} \mathrm{~L}_{14-9}$ & $\mathrm{Q}_{90-95} \mathrm{~F}_{1} \quad \mathrm{~L}_{9-4}$ \\
\hline $\begin{array}{l}\text { Grain } \\
\text { Textures }\end{array}$ & $\begin{array}{l}\text { Rounded, subrounded } \\
\text { frosted quartz grains }\end{array}$ & $\begin{array}{l}\text { Rounded, subrounded } \\
\text { frosted quartz grains }\end{array}$ \\
\hline $\begin{array}{l}\text { Heavy } \\
\text { Minerals }\end{array}$ & $\begin{array}{l}\text { Metastable group: } \\
\mathrm{Cl}_{20-40} \mathrm{H}_{35-60} \mathrm{E}_{10-17} \\
\text { Ultra-stable group: } \mathrm{Z} \\
\text { (C1=clinopyroxene, } \\
\mathrm{H}=\text { hornblende; } \\
\mathrm{E}=\text { epidote) }\end{array}$ & $\begin{array}{l}\text { Ultra-stable group: } \\
\mathrm{Z}_{63}{ }^{\mathrm{T}}{ }_{15}{ }^{\mathrm{R}} 13 \\
\text { Metastable group: } \mathrm{G}_{9} \\
\text { (G=garnet; } \mathrm{Z}=\text { zircon; } \\
\mathrm{T}=\text { tourmaline; } \\
\mathrm{R}=\text { rutile) }\end{array}$ \\
\hline Source & $\begin{array}{l}\text { Recycled sands } \\
\text { (Nubian sand) }\end{array}$ & $\begin{array}{l}\text { Recycled sands } \\
\text { (Nubian type sand } \\
\text { facies: Sahara) }\end{array}$ \\
\hline $\begin{array}{l}\text { Mode of } \\
\text { Transport }\end{array}$ & $\begin{array}{l}\text { Turbidity currents } \\
\text { Mass flows }\end{array}$ & $\begin{array}{l}\text { Turbidity currents } \\
\text { Mass flows }\end{array}$ \\
\hline $\begin{array}{l}\text { Environment } \\
\text { of Deposition }\end{array}$ & $\begin{array}{l}\text { Continental Rise-Cone } \\
\text { (interchannel area) }\end{array}$ & $\begin{array}{l}\text { Channel filling "fluxo- } \\
\text { turbidites" on an an- } \\
\text { cient Continental Rise }\end{array}$ \\
\hline
\end{tabular}

TABLE 7

Comparison of Nile Cone Fine-Grained "Black Clays" and the North African Numidian Flysch (Facies 2) of Sicily

\begin{tabular}{|c|c|c|}
\hline & $\begin{array}{l}\text { Nile Cone } \\
\text { "Black Clays" }\end{array}$ & $\begin{array}{c}\text { Numidian Flysch of } \\
\text { Sicily Argilites } \\
\text { (Wezel, 1970) Facies } 2\end{array}$ \\
\hline $\begin{array}{l}\text { Facies } \\
\text { description }\end{array}$ & Terrigenous black clays & \pm Silty argilites \\
\hline $\begin{array}{l}\% \mathrm{CaCO}_{3} \\
\text { calcium } \\
\text { carbonate }\end{array}$ & low: $<5 \%$ & low: $<5 \%$ \\
\hline Color & Dark gray to black & Dark brown or dark gray \\
\hline $\begin{array}{l}\text { Fe-Mn } \\
\text { oxides }\end{array}$ & $\begin{array}{l}\text { Trace metals com- } \\
\text { plexed in organic mat- } \\
\text { ter and as stains on } \\
\text { mineral grains, hydro- } \\
\text { triolite bandings, } \\
\text { abundant pyrite, and } \\
\text { some siderite }\end{array}$ & $\begin{array}{l}\text { The argilites are rich of } \\
\text { diagenetic iron minerals }\end{array}$ \\
\hline Composition & $\begin{array}{l}\text { Montmorillonite + } \\
\text { Kaolinite + Illite }\end{array}$ & $\begin{array}{l}\text { Kaolinite + mixed layers of } \\
\text { illite-montmorillonite }+ \\
\text { illite + chlorite }\end{array}$ \\
\hline Source & Nile River bed load & $\begin{array}{l}\text { Fe oxides seems to indi- } \\
\text { cate laterite conditions }\end{array}$ \\
\hline $\begin{array}{l}\text { Mode of } \\
\text { transport }\end{array}$ & $\begin{array}{l}\text { Predominantly tur- } \\
\text { budity currents, per- } \\
\text { haps also laterally } \\
\text { reworked and } \\
\text { distributed by } \\
\text { contour currents }\end{array}$ & $\begin{array}{l}\text { Turbidity currents and } \\
\text { contour currents }\end{array}$ \\
\hline
\end{tabular}

This second source is inferred to be from the north and must have supplied the Levantine Basin before the formation of topographic barriers such as the Pliny Trench and Strabo Mountains. Consequently, it is fair to conclude that the present physiography of the eastern Mediterranean is relatively young, and that contemporary earthquake activity might be viewed as a manifestation of continuing deformation and reorganization.

\section{ACKNOWLEDGMENTS}

The authors acknowledge enlightening discussions with the shipboard staff on the Glomar Challenger and in particular mineralogical identifications made by W. D. Nesteroff and G. Pautot. The Vema and Conrad piston cores were obtained with research vessels of the LamontDoherty Geological Observatory of Columbia University under the supervision of Maurice Ewing. Ryan and Venkatarathnam have been supported by the Office of Naval Research and the U.S. National Science Foundation, and Wezel by the Consiglio Nazionale delle Ricerche (Comitato per le science geologiche e minerarie). This is LDGO contribution No. 1859 .

\section{REFERENCES}

Aubouin, J., 1965. Geosynclines, In Developments in Geotectonics. Elsevier, Amsterdam. 1, 1.

Biscaye, P. E., 1964. Distinction between chlorite and kaolinite in recent sediments by X-ray diffraction. $\mathrm{Am}$. Mineral. 49, 1281.

, 1965. Mineralogy and sedimentation of recent deep-sea clay in the Atlantic Ocean and adjacent seas and oceans. Bull. Geol. Soc. Am. 76, 803.

Boyce, R. E. and Bode, G. W., 1972. Carbon and carbonate 


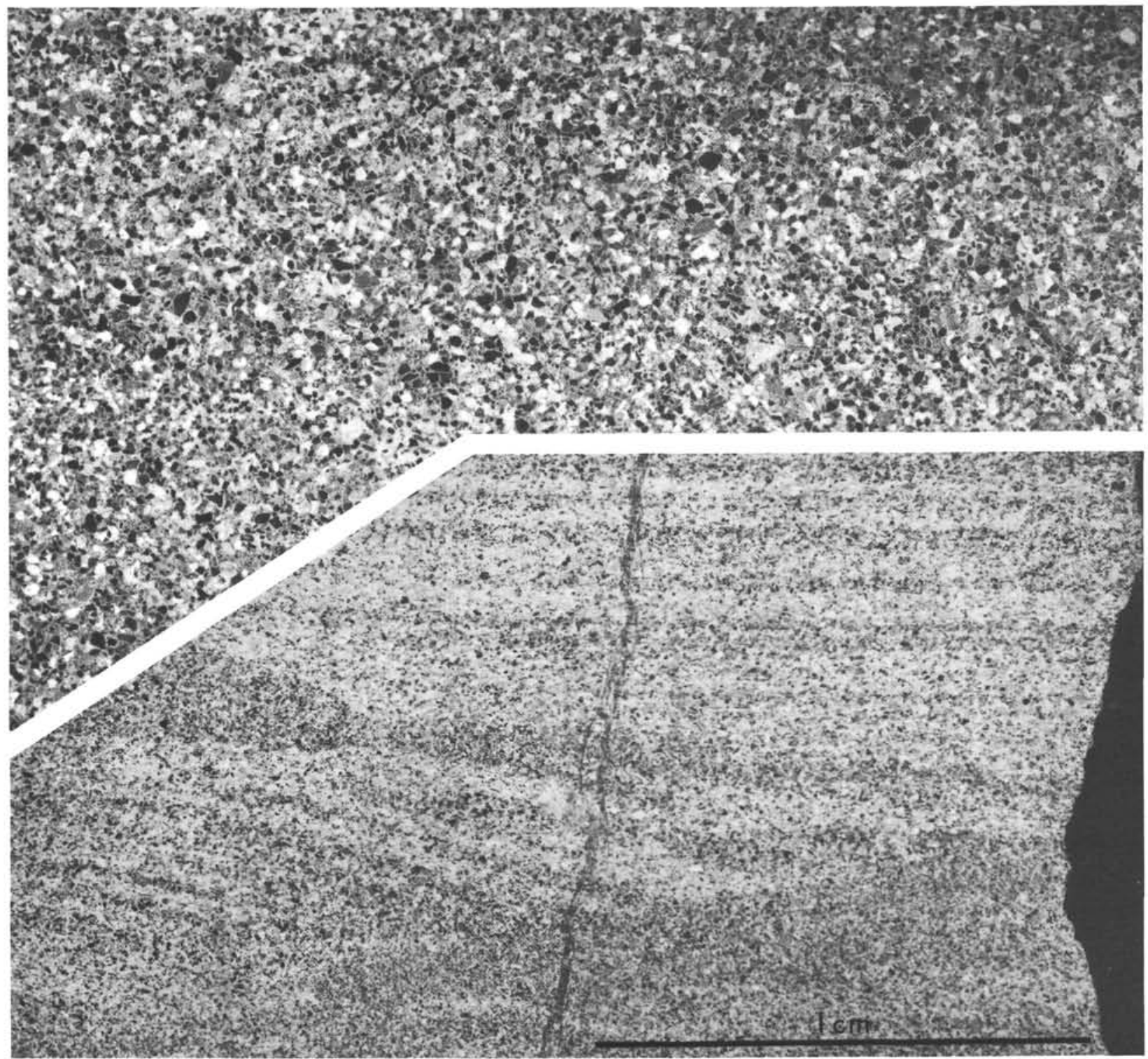

Figure 13. Reversal prints of volcanic and metamorphic rich (lithic sandstones) greywackes. The coarse-grained standstone is Sample 129B, 2 CC from the Strabo Trench, and the cross-bedded siltstone is Sample V10-64 from the Hellenic Trough south of Crete.

analyses, Leg 9, In Hays, J. D., et al. Initial Reports of the Deep Sea Drilling Project, Volume IX. Washington. (U.S. Government Printing Office). 797.

Bruun, J. H., 1960. Les zones hèlleniques internes et leur extension. Rèflexions sur l'orogenèse alpine. Bull. Geol. Soc. France, sèr. 7, 2, 470.

Butzer, K. W. and Hansen, C. L., 1968. Desert and River in Nubia geomorphology and prehistoric environments at Aswan Reservoir. Univ. of Wisconsin Press. Madison. $562 \mathrm{p}$.

Chumakov, I. S., 1967. Pliocene and Pleistocene deposits of the Nile Valley in Nubia and Upper Egypt. Acad. Sci. USSR, Geol. Inst. "Nauka," Moscow. 1.

Elgabaly, M. M. and Khadr, M., 1962. Clay mineral studies of some Egyptian desert and Nile alluvial soils. J. Soil Sci, 13, 333.

Emelyanov, E. M., 1968. Mineralogy of the sand-silt fraction of recent sediments of the Mediterranean Sea,
Lithology and Mineral Resources, p. 127-142 (a translation from Litologyia i Poleznye Iskopaemye). 2, 3.

Emery, K. O. and George, C. J., 1963. The shores of Lebanon, The American University of Beirut. Miscellaneous Papers in the Natural Sciences. 1, 1.

Emery, K. O. and Neev, D., 1960. Mediterranean beaches of Israel. Israel Geological Survey Bulletin. 26, 1.

Grim, R. E., Bray, R. H. and Bradley, W. F., 1937. The mica in argillaceous sediments. Am. Mineralogist 22, 813.

Hersey, J. B., 1965. Sedimentary basins of the Mediterranean Sea. In Submarine Geology and Geophysics. W. F. Whittard and R. Bradshaw, (Eds.) Proc. 17th Symposium Colston Res. Soc., Apr. 5-9, Butterworth, London, 75.

Krinsley, D. H. and Donahue, J., 1968. Environmental interpretation of sand grain surface textures by electron microscopy. Bull. Geol. Soc. Am. 79, 743. 
TABLE 8

Diagnostic Features Contrasting the Nile Provenance and Inferred Northern Provenance

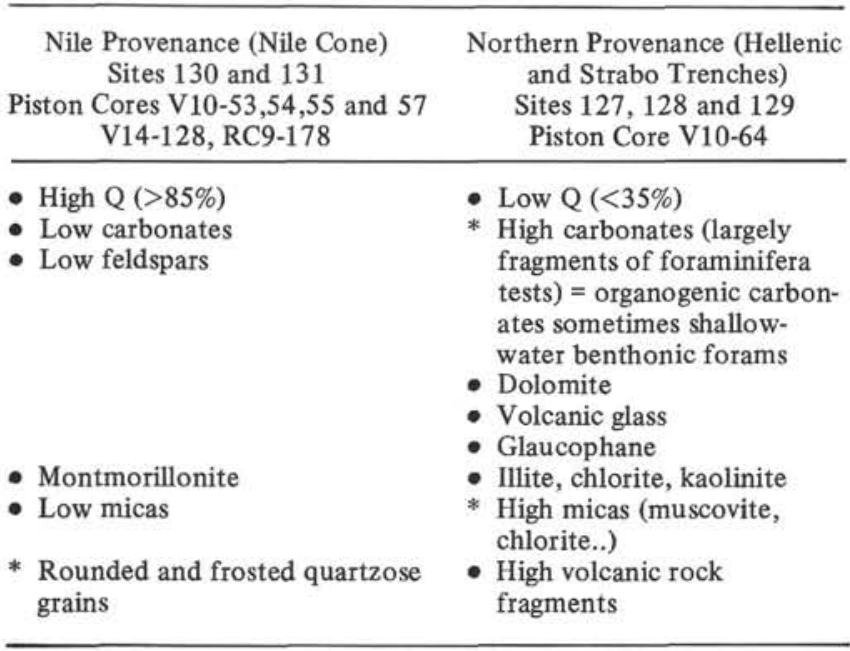

* key properties

Kuenen, Ph. H., 1962. Experimental abrasion 5. Frosting and defrosting of quartz grains, J. Geol. 70, 648 .
Mitchell, A. H. and Reading, H. G., 1969. Continental margins, geosynclines, and ocean floor spreading. $J$. Geol. 77, 629 .

Smith, A. G., 1971. Alpine deformation and the oceanic areas of the tethys, Mediterranean, and Atlantic. Bull. Geol. Soc. Am. 82, 2039.

Sukhri, N. M., 1950. The mineralogy of some Nile sediments. Geol. Soc. London Q. J. 105, 513; 106, 466. 1951. Mineral analyses tables of some Nile sediments. Bull. Inst. Fouad l-er du desert. 1, 2.

Venkatarathnam, K. and Ryan, W. B. F., 1971. Dispersal patterns of clay minerals in the sediments of the eastern Mediterranean. Marine Geol. 11, 261.

von Rad, V., 1968. Comparison of sedimentation in the Vabarian flysch (Cretaceous) and Recent San Diego Trough (Calif.). J. Sediment. Petrol. 38 (4), 1120.

Wezel, F. C., 1970. Geologia del Flysch Numidio della sicilia Nord-orientale. Mem. Soc. Geologia Italiana. 9, 225.

Wezel, F. C. and Ryan, W. B. F., 1971. Flysch, margini continentali e zolle litosferiche. Boll. Soc. Geol. It. 90, 249.

Woodside, J. M., and Bowin, C. O., 1970. Gravity anomalies and inferred crustal structure in the eastern Mediterranean Sea. Bull. Geol. Soc. Am. 81, 1107. 